\title{
Attrition Resistant Catalysts for Slurry-Phase Fischer-Tropsch Process
}

November 1999

Final Report

Work Performed Under Grant No: DE-FG26-98FT40108--01

U.S. Department of Energy Federal Energy Technology Center Pittsburgh, PA 15236

by

K. Jothimurugesan Department of Chemical Engineering Hampton University Hampton, VA 23668 


\section{Attrition Resistant Catalysts for Slurry-Phase Fischer-Tropsch Process}

\section{Final Report}

Work Performed Under

Grant No: DE-FG26-98FT40108

for

U.S. Department of Energy

Federal Energy Technology Center

Pittsburgh, PA 15236

by

K. Jothimurugesan

Department of Chemical Engineering

Hampton University

Hampton, VA 23668

November 1999 


\section{DISCLAIMER}

This report was prepared as an account of work sponsored by an agency of the United States Government. Neither the United States Government nor any agency thereof, nor any of their employees, makes any warranty, express or implied, or assumes any legal liability or responsibility for the accuracy, completeness, or usefulness of any information, apparatus, product, or process disclosed, or represents that its use would not infringe privately owned rights. Reference herein to any specific commercial product, process, or service by trade name, trademark, manufacturer, or otherwise, does not necessarily constitute or imply its endorsement, recommendation, or favoring by the United States Government or any agency thereof. The views and opinions of authors expressed herein do not necessarily state or reflect those of the United States Government or any agency thereof. 


\begin{abstract}
The Fischer-Tropsch (F-T) reaction provides a way of converting coal-derived synthesis gas $\left(\mathrm{CO}+\mathrm{H}_{2}\right)$ to liquid fuels. Since the reaction is highly exothermic, one of the major problems in control of the reaction is heat removal. Recent work has shown that the use of slurry bubble column reactors (SBCRs) can largely solve this problem. Iron-based $(\mathrm{Fe})$ catalysts are preferred catalysts for F-T because they are relatively inexpensive and possess reasonable activity for F-T synthesis (FTS). Their most advantageous trait is their high water-gas shift (WGS) activity compared to their competitor, namely cobalt. This enables Fe F-T catalysts to process low $\mathrm{H}_{2} / \mathrm{CO}$ ratio synthesis gas without an external shift reaction step. However, a serious problem with the use of Fe catalysts in a SBCR is their tendency to undergo attrition. This can cause fouling/plugging of downstream filters and equipment, makes the separation of catalyst from the oil/wax product very difficult if not impossible, and results a steady loss of catalyst from the reactor.
\end{abstract}

The objectives of this research were to develop a better understanding of the parameters affecting attrition of Fe F-T catalysts suitable for use in SBCRs and to incorporate this understanding into the design of novel Fe catalysts having superior attrition resistance.

A Ruhrchemie iron catalyst of composition $100 \mathrm{Fe} / 5 \mathrm{Cu} / 4.2 \mathrm{~K} / 25 \mathrm{SiO}_{2}$ was obtained and tested for FT activity in a $1 \mathrm{~cm}$ i.d. high pressure fixed bed micro-reactor system. This catalyst will serve as a baseline catalyst for this work from which improvements in activity will be sought. A cobalt catalyst with $20 \%$ of cobalt prepared using incipient wetness of a spray dried silica is also used as a bench mark. This cobalt catalyst was found to be suitable for use in an SBCR. This cobalt catalyst will serve as a baseline catalyst for this work from which 
improvements in attrition will be sought. The effect of binder (binder silica and kaoline clay binder ) on catalyst attrition and activity to a doubly promoted FT iron catalysts (100/Fe/5 $\mathrm{Cu} / 4.2 \mathrm{~K}$ ) was studied.

The catalysts were prepared by coprecipitation, followed by binder addition and spray drying at $250^{\circ} \mathrm{C}$ in a $1 \mathrm{~m}$ diameter, $2 \mathrm{~m}$ tall spray dryer. The binder silica content was varied from 0 to $20 \%$ and the kaoline clay binder was varied from 0 to $24 \%$. The comparison of the attrition results shows that some of the spray dried iron catalysts in their calcined state are physically as strong as, or stronger than, the cobalt catalysts. These iron catalysts are therefore considered to have a strong potential for SBCR use. A catalyst with $12 \%$ binder silica was found to have the highest attrition resistance. The addition of kaolin causes more attrition.

The FT activity and selectivity of the catalyst containing binder silica are better than the Ruhrchemie catalyst at $250 \mathrm{EC}$ and $1.48 \mathrm{MPa}$. F-T reaction studies over 100 hours in a fixed-bed reactor showed that this catalyst maintained around $95 \% \mathrm{CO}$ conversion with a methane selectivity of less than $7 \mathrm{wt} \%$ and $\mathrm{a} \mathrm{C}_{5}{ }^{+}$selectivity of greater than $73 \mathrm{wt} \%$. Addition of kaolin binder to catalyst containing $10 \%$ binder silica was detrimental to FT activity. CO conversion dropped from 94 to $42.8 \%$ as kaolin content increased from 0 to 24 wt \%. The methane selectivity also increased with kaolin content up to $12 \mathrm{wt} \%$. The alpha value for all catalysts tested ranged from 0.88 to 0.91 . 


\section{ACKNOWLEDGMENTS}

This study was sponsored by the U.S. Department of Energy (DOE) under Grant No: DEFG26-98FT40108. The author would like to acknowledge with gratitude the guidance provided by the DOE Contracting Officer's Representative, Dr. Udaya S. Rao 


\section{CONTENTS}

$\underline{\text { Section }}$

$\underline{\text { Page }}$

Abstract ........................................................... 3

Acknowledgments .............................................. 5

List of Tables .................................................

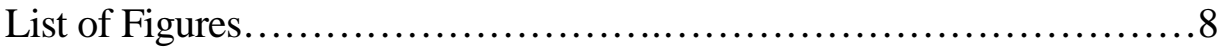

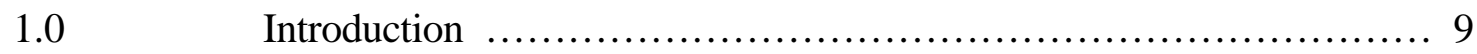

$1.1 \quad$ Project Objectives................................................ 11

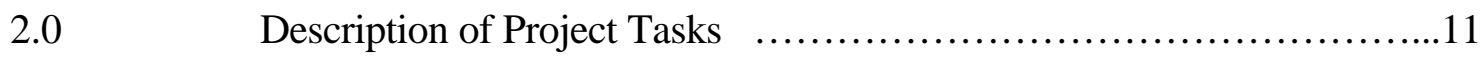

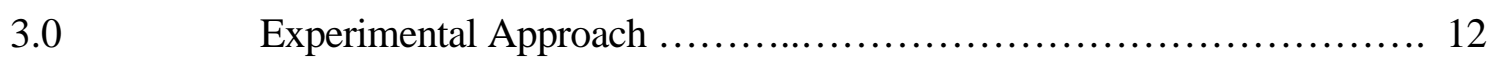

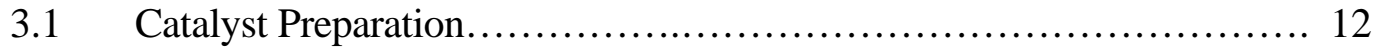

$3.2 \quad$ Catalyst Characterization .......................................... 14

3.3 Apparatus and Procedures............................................ 16

Results and Discussions ......................................... 18

Conclusions......................................................... 30

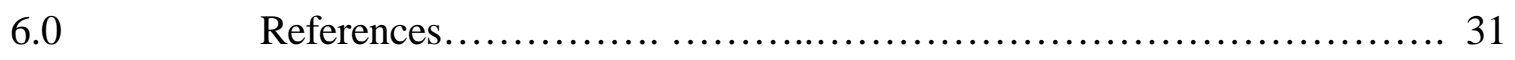




\section{LIST OF TABLES}

Number

$\underline{\text { Page }}$

1 Catalyst Designation and Binder Content............................ 13

2 ASTM Fluid Bed Test Results....................................... 20

3 Physical and Chemical Properties of Fe Catalysts......................... .23

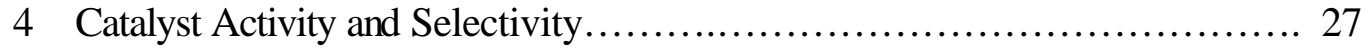




\section{LIST OF FIGURES}

$\underline{\text { Page }}$

1 Catalyst Preparation Procedure.............................................. 14

2 Schematic Diagram of the Laboratory-Scale Fixed-Bed Reactor .................. 17

3 SEM Image of Spray Dried Iron Catalysts (a) Fe-bSi(12) (b) Fe-KL(12) . .... . . . 19

4 TPR Profile (a) Fe-bSi(12) (b) Fe-KL(12) Catalysts............................ 22

5 XRD Spectra of Fe-bSi(12) catalysts (a) As-Prepared Fresh Catalysts (b) Activation in $\mathrm{CO}$ for $16 \mathrm{~h}$ at $280^{\circ} \mathrm{C}$ ( c) Activation in CO followed by

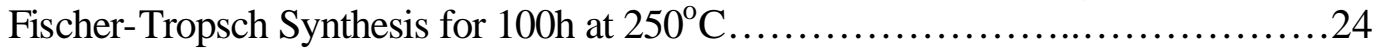

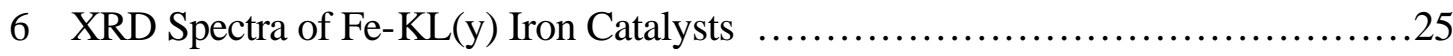

7 Effect of Binder Silica on Synthesis Gas Conversion and Catalyst Stability.........28

8 Effect of Kaolin Binder Synthesis Gas Conversion and

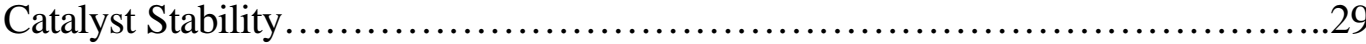




\section{Attrition Resistant Catalysts for Slurry-Phase Fischer-Tropsch Process}

\subsection{INTRODUCTION}

Fischer-Tropsch synthesis (FTS) is a set of reactions by which $\mathrm{CO}$ and $\mathrm{H}_{2}$ (syn gas) are converted into a wide variety of hydrocarbons extensively (Dry 1981, Anderson 1984, Kolbel 1980). This synthesis provides the best means currently available for the conversion of coal into synthetic transportation fuels. While over the near to mid term this indirect coal liquefaction route is not likely to be competitive with cheap oil on a global basis, there are a number of commercial activities in this area. SASTECH is making commercially synthetic fuels and chemicals by FTS from coal, China plans to make town gas via this route, and Williams Company is constructing a pilot plant to determining the economics of underground coal gasification, while Shell is using FTS commercially to convert natural gas to high value products. Improvements and innovation in FTS is strategically very important to the U.S. because of its vast coal reserves and because it represents the best way to make high quality liquid products from coal.

Since the gasification of coal gives syn gas relatively lean in hydrogen $\left(\mathrm{H}_{2} / \mathrm{CO} \tilde{0} 0.5-0.7\right)$, the use of a catalyst which converts the oxygen of the $\mathrm{CO}$ to $\mathrm{CO}_{2}$ rather than $\mathrm{H}_{2} \mathrm{O}$ is preferable. This is achieved by using catalysts which, in addition to being active for FTS, are also active for the water gas shift reaction (WGS):

$$
\mathrm{CO}+\mathrm{H}_{2} \mathrm{OWCO}_{2}+\mathrm{H}_{2}
$$

Fe is the preferred catalyst since it is one of the more active FTS catalysts, active for the WGS reaction, and relatively inexpensive. 
Because FTS is so exothermic, one of the major problems in control of the reaction is heat removal. Recent work by industry (Gulf, Statoil, Exxon, SASOL/ SASTECH, Rentech, and others), DOE, and universities has concentrated on the use of slurry-phase reactors, especially slurry bubble column reactor (SBCRs), which are able to be controlled more easily because of the liquid phase present (Dry 1981; Anderson 1984; Bukur, D.B., et al., 1990 a, b; Pennline et al., 1987; Zarochak and McDonald, 1987; Sault and Datye, 1993; Butt, 1990; Bukur et al., 1995a; 1995b). Such reactors have relatively simple designs and low initial costs while still permitting high catalyst and reactor productivity.

Obviously, much recent work related to slurry-phase FTS based on coal-derived syn gas has focused on using Fe catalysts. Unfortunately, the use of Fe catalysts in SBCRs have been found to present a number of problems. Because of the difficulty in reducing highly dispersed Fe and its lower FTS activity than Co (which does not posses much WGS activity) or Ru (which is too expensive to use by itself), bulk Fe catalysts have had to be used in order to have sufficient active surface area per catalyst weight. The Fe catalysts used in SBCRs have been usually prepared by precipitation, one of the typical methods of preparation of Fe catalysts for use in fixed bed reactors.

The problems encountered in using precipitated iron catalysts is mainly due their attrition properties. Since SBCRs are used to produce high alpha (") FTS products, there is a need to easily and inexpensively separate the catalyst from the liquid products. The apparent density of typical precipitated Fe catalysts is estimated to be very close (near $0.7 \mathrm{~g} / \mathrm{cm}^{3}$ ) to that of FischerTropsch wax (about $0.68 \mathrm{~g} / \mathrm{cm}^{3}$ ) at reaction conditions (Donnelly, 1989). While this is beneficial for keeping the catalyst slurried, catalyst separation from the products can be difficult since the catalyst does not settle well. 
Although internal/external filtration systems can be incorporated with slurry reactors, plugging of the filters by Fe catalyst particles is encountered. This is due to the low attrition resistance of the Fe catalyst and the significant breakage of the Fe particles. Fe catalysts are subject to both chemical as well as physical attrition in a SBCR. Chemical attrition can be caused due to phase changes that any $\mathrm{Fe}$ catalyst goes through $\left(\mathrm{Fe}_{2} \mathrm{O}_{3}{ }^{2} \mathrm{Fe}_{3} \mathrm{O}_{4}{ }^{2} \mathrm{FeO}^{2} \mathrm{Fe}\right.$ metal ${ }^{2} \mathrm{Fe}$ carbides) potentially causing internal stresses within the particle and resulting in weakening, spalling or cracking (Shroff et al., 1995). Physical attrition can result due to collisions between catalyst particles and with reactor wall. Catalyst particles of irregular shapes and non-uniform sizes produced by conventional methods are subject to greater physical attrition. Recently, there has been an in-depth development of precipitated Fe catalysts for use in the slurry phase at the University of Kentucky (O'Brian et al., 1995). However, none of the catalysts produced by this route appears to offer much improvement in attrition resistance.

\subsection{Project Objectives}

The objectives of the project were to (1) develop a better understanding of the parameters affecting attrition resistance of Fe F-T catalysts suitable for use in SBCRs and (2) incorporate this understanding into the design of Fe catalysts having superior attrition resistance. The goal was to develop an Fe catalyst, without sacrificing FTS activity and selectivity, which can be used in a SBCR having only an internal filter for separation of the catalyst

\subsection{DESCRIPTION OF PROJECT TASKS}

\section{TASK 1: $\quad$ Catalyst Preparation}

The objectives of this task were to prepare precipitated iron catalyst with various levels of silica binder and kaolin binder. Several parameters were varied in the catalyst preparation to 
study their effect on the catalyst attrition, activity and selectivity. Section 3.1 describes the detailed catalyst preparation procedure employed in this study.

\section{TASK 2: $\quad$ Catalyst Characterization}

The objectives of this task were to characterize the fresh, reduced and used catalysts.

Section 3.2 describes the various analytical techniques employed for catalyst characterization throughout the project.

\section{TASK 3: $\quad$ Catalyst Performance Evaluation}

The objectives of this task were to evaluate the performance of various catalyst compositions under similar conditions in a fixed-bed microreactor. Section 3.3 describe the experimental apparatus and procedures employed throughout the project. Catalyst comparisons were carried out at the following operating conditions:

Pretreatment: $\mathrm{CO}, 280^{\circ} \mathrm{C}, 16 \mathrm{~h}$

Temperature: $250^{\circ} \mathrm{C}$

Pressure: $\quad 1.48 \mathrm{MPa}$

$\mathrm{SV}: \quad 2 \mathrm{~nL} /(\mathrm{g}$ of cat $/ \mathrm{h})$

$\mathrm{H}_{2} / \mathrm{CO}: \quad 0.67$

The catalyst was tested over a period of 75 to $100 \mathrm{~h}$.

\subsection{EXPERIMENTAL APPROACH}

\subsection{Catalyst Preparation}

A standard Ruhrchemie precipitated Fe catalyst (Identified as Batch 52119) was obtained from the U.S. Department of Energy (DOE) as a benchmark catalyst. The composition of this catalyst was $100 \mathrm{Fe} / 5 \mathrm{Cu} / 4.2 \mathrm{~K} / 25 \mathrm{SiO}_{2}$. It contained 25 parts by weight (pbw) precipitated silica. It was obtained as a $1 / 8$ in. extrudate and was crushed to 50 to $100: \mathrm{m}$ particles prior to use. 
In this study, all catalysts were prepared with the same ratio of iron, copper, and potassium $(100 \mathrm{Fe} / 5 \mathrm{Cu} / 4.2 \mathrm{~K})$ as the benchmark catalyst, but with differing levels of binder silica and kaolin binder. Two types of catalysts were prepared as shown in Table 1.

Table 1. Catalyst Designation and Binder Content

\begin{tabular}{|lcc|}
\hline Catalyst Series & Binder Silica (wt \%) & Kaolin Binder (wt \%) \\
\hline Fe-bSi $(\mathrm{x})$ & $\mathrm{x}$ & 0 \\
Fe-KL(y) & 10 & $\mathrm{y}$ \\
Ruhrchemie & 0 & 0 \\
& & \\
\hline
\end{tabular}

Catalyst preparation involved four steps: preparation of the iron and copper precursor; incorporation of potassium; addition of binder silica, and kaolin binder; and finally spray drying. Binder silica and kaolin binder containing iron catalysts were prepared and the procedure is shown in Figure 1. The first series of catalyst contained binder silica but no kaolin binder had a composition of $100 \mathrm{Fe} / 5 \mathrm{Cu} / 4.2$ (plus binder silica). The binder silica preparation and addition method is proprietary. These catalysts were prepared by coprecipitation using an aqueous solution containing $\mathrm{Fe}\left(\mathrm{NO}_{3}\right)_{3} \cdot 9 \mathrm{H}_{2} \mathrm{O}$ and $\mathrm{Cu}\left(\mathrm{NO}_{3}\right)_{3} \cdot 2.5 \mathrm{H}_{2} \mathrm{O}$ in the desired $\mathrm{Fe} / \mathrm{Cu}$ atomic ratio, which was precipitated by adding ammonium hydroxide. The resulting precipitate was then filtered and washed three times with deionized water. The potassium promoter was added as aqueous $\mathrm{KHCO}_{3}$ solution to the undried, reslurried $\mathrm{Fe} / \mathrm{Cu}$ coprecipitate. To this catalyst, five different levels of binder silica were added: 4,8,12,16 and $20 \mathrm{wt} \%$. These catalysts were then spray dried at $250^{\circ} \mathrm{C}$ using a large bench-scale Niro spray dryer, $3 \mathrm{ft}$ diameter x $6 \mathrm{ft}$ high. Finally, the spray dried catalyst was calcined at $300^{\circ} \mathrm{C}$ for $5 \mathrm{~h}$ in a muffle furnace. These catalysts are designated $\mathrm{Fe}-\mathrm{bSi}(\mathrm{x})$, denoting that they contain $\mathrm{x} \%$ binder silica.

The second series of catalysts contained both binder silica and kaolin binder. The kaolin binder was prepared by diluting kaolin with distilled water following the procedure described by 
Demmel (1994). To the diluted kaolin, $85 \%$ phosphoric acid was added, followed by 40 wt \% dibasic ammonium phosphate to bring the slurry $\mathrm{pH}$ to 7.0. To each of these catalysts, $10 \mathrm{wt} \%$ binder silica was added (yielding catalysts of the composition $100 \mathrm{Fe} / 5 \mathrm{Cu} / 4.2 \mathrm{~K} / \mathrm{xSiO}$, where $\mathrm{x}$ is 10 wt \%). Five such catalyst were prepared containing 8,12,16,20 and $24 \%$ kaolin binder. These catalysts are designated Fe-KL(y). These catalysts were then spray dried and calcined in the same way as those above.

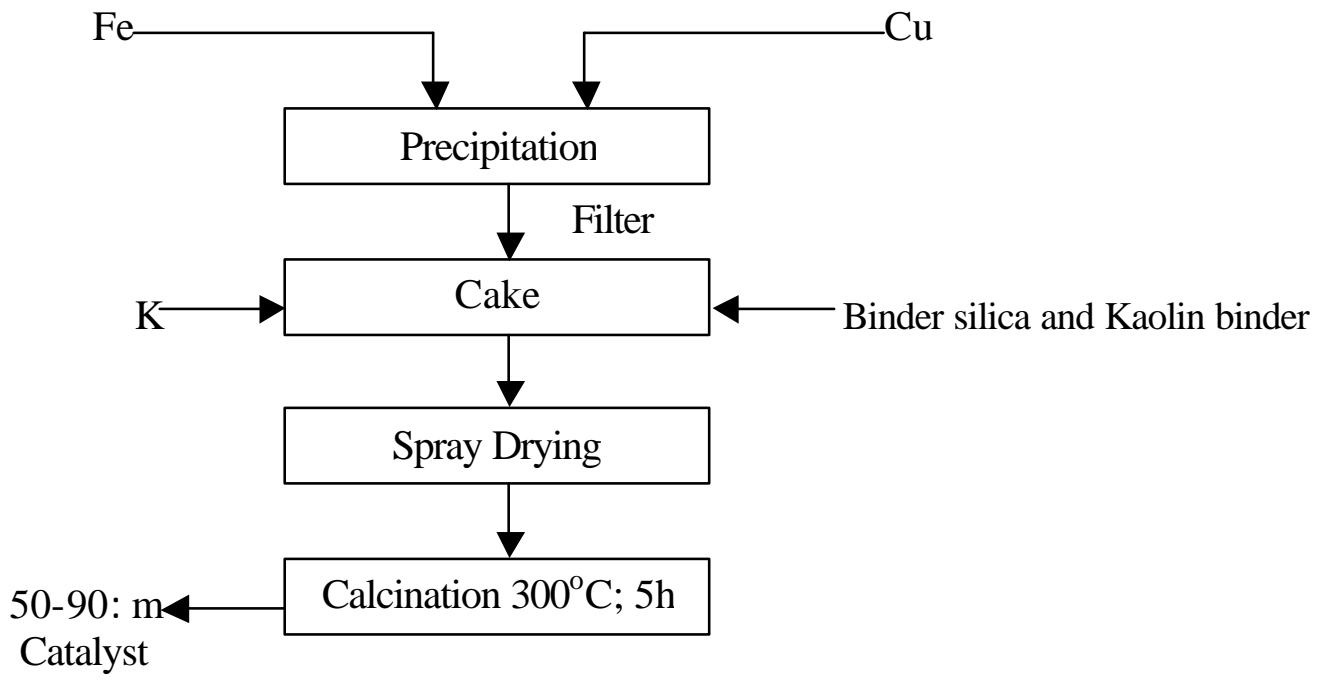

Figure 1. Catalyst Preparation Procedure

\subsection{Catalyst Characterization}

Detailed physical and chemical characterization of the fresh, reduced and used catalysts were carried out using the following analytical techniques.

The BET surface area of the catalysts was determined by $\mathrm{N}_{2}$ physisorption using a Micromeritics Gemini 2360 system. The samples were degassed in a Micromeritics Flow Prep 060 at $120^{\circ} \mathrm{C}$ for $1 \mathrm{~h}$ prior to each measurement. The SEM micrograph was taken using a Cambridge Stereoscan 100. X-ray powder diffraction patterns were obtained using a Phillips 
PW1800 x-ray unit using CuK" radiation. Analyses were conducted using a continuous scan mode at a scan rate of $0.05^{\circ} 22$ per second.

For determination of the reduction behavior and the reducibility of the catalysts, TPR experiments were carried out using a Micromeritics 2705 TPR/TPD system. A sample close to $0.2 \mathrm{~g}$ was dried and degassed under high purity $\mathrm{Ar}$ at $400^{\circ} \mathrm{C}$ for $1 \mathrm{~h}$ followed by cooling to ambient temperature. Reduction was achieved under $\mathrm{H}_{2} / \mathrm{Ar}$ gas mixture (volume ratio 5/95). Total gas flow was $40 \mathrm{cc} / \mathrm{min}$ and temperature program was 25 to $900^{\circ} \mathrm{C}$ at a heating rate of $10^{\circ} \mathrm{C} / \mathrm{min}$. Hydrogen consumed by the catalyst was detected using a thermal conductivity detector (TCD) and recorded as a function of temperature.

The attrition of the catalysts was measured using a three-hole air-jet attrition tester per ASTM-D-5757-95. This test method is applicable to spherically or irregularly shaped particles that range in size between 10 and 180 micrometers, have skeletal densities between 2.4 and 3.0 $\mathrm{g} / \mathrm{cm}^{3}$, and are insoluble in water. Particles less than 20 microns are considered fines. The heart of the system is the vertical attriting tube, a stainless steel tube $710 \mathrm{~mm}$ long with an inside diameter of $35 \mathrm{~mm}$. There is an orifice plate attached to the bottom of this tube with three 2-mm long drilled sapphire square-edged nozzles. The nozzles are precision drilled $0.381+/-0.005 \mathrm{~mm}$ in diameter. Above the attriting tube is the settling chamber, a 300-mm long cylinder with a 110 - $\mathrm{mm}$ inside diameter. Finally, there is a fines collection assembly made up of a 250-mL filtering flask and an extraction thimble. There is additional peripheral equipment required to provide the source of humidified air (30-40\% relative humidity) that the test method requires. To conduct a test, a sample of dried powder is humidified and attrited by means of three high velocity jets of humidified air. The fines are continuously removed from the attrition zone by elutriation into a fines collection assembly. The attrition index (AI) is calculated from the 
elutriated fines to give a relative estimate of the attrition resistance of the powdered catalyst as may be observed in commercial use.

The full test protocol calls for $45 \mathrm{~g}$ of a screened and dried representative sample to be humidified with $5 \mathrm{~g}$ of demineralized water to produce $50 \mathrm{~g}$ of water equilibrated sample. This sample is run in the apparatus for 5 hours, with an intermediate change of the fines filter at one hour elapsed time. The AI is based on the fines loss after 1 hour and 5 hours.

\subsection{Apparatus and Procedures}

The catalysts prepared were tested in a laboratory scale high-pressure and high temperature fixed bed reactor which is shown in Figure 2. Briefly, the fixed-bed reactor was constructed of 1-c.m-i.d. stainless steel tube. The iron F-T catalysts were pretreated under flowing $\mathrm{CO}$ at $280^{\circ} \mathrm{C}$ for $16 \mathrm{~h}$ before reaction. Following catalyst pretreatment, the reactor temperature was decreased to $50^{\circ} \mathrm{C}$. CO flow was stopped, and synthesis gas was introduced at a gas space velocity of $2.0 \mathrm{NL} / \mathrm{g}$-cat/h. The synthesis gas was a premixed gas of $\mathrm{CO}$ and $\mathrm{H}_{2}$ $\left(\mathrm{H}_{2} / \mathrm{CO}=0.67\right)$ containing $5 \% \mathrm{Ar}$ as an internal standard for product analysis. The reactor system was then pressurized to $1.48 \mathrm{MPa}$. The reactor temperature was then increased gradually to $250^{\circ} \mathrm{C}$. This is referred to as the conditioning period. After achieving, the desired process condition of $250^{\circ} \mathrm{C}, 1.48 \mathrm{MPa}, 2.0 \mathrm{NL} / \mathrm{g}$-cat/h and $\mathrm{H}_{2} / \mathrm{CO}=0.67$, the catalyst was tested over a period of 100 to $125 \mathrm{~h}$.

The product gas was analyzed by an online Hewlett-Packard (HP) 5890 Series II plus gas chromatograph (GC), with advanced Chemstation control and capabilities. The HP 3365 Series II Chemstation offered automatic flow and split ratio of GC pneumatics. Three valves were used in the system: a 6-port gas sampling valve, a 10-port gas sampling valve with backflush to vent, and a 6-port column isolation valve. The system was configured for an extended analysis of 


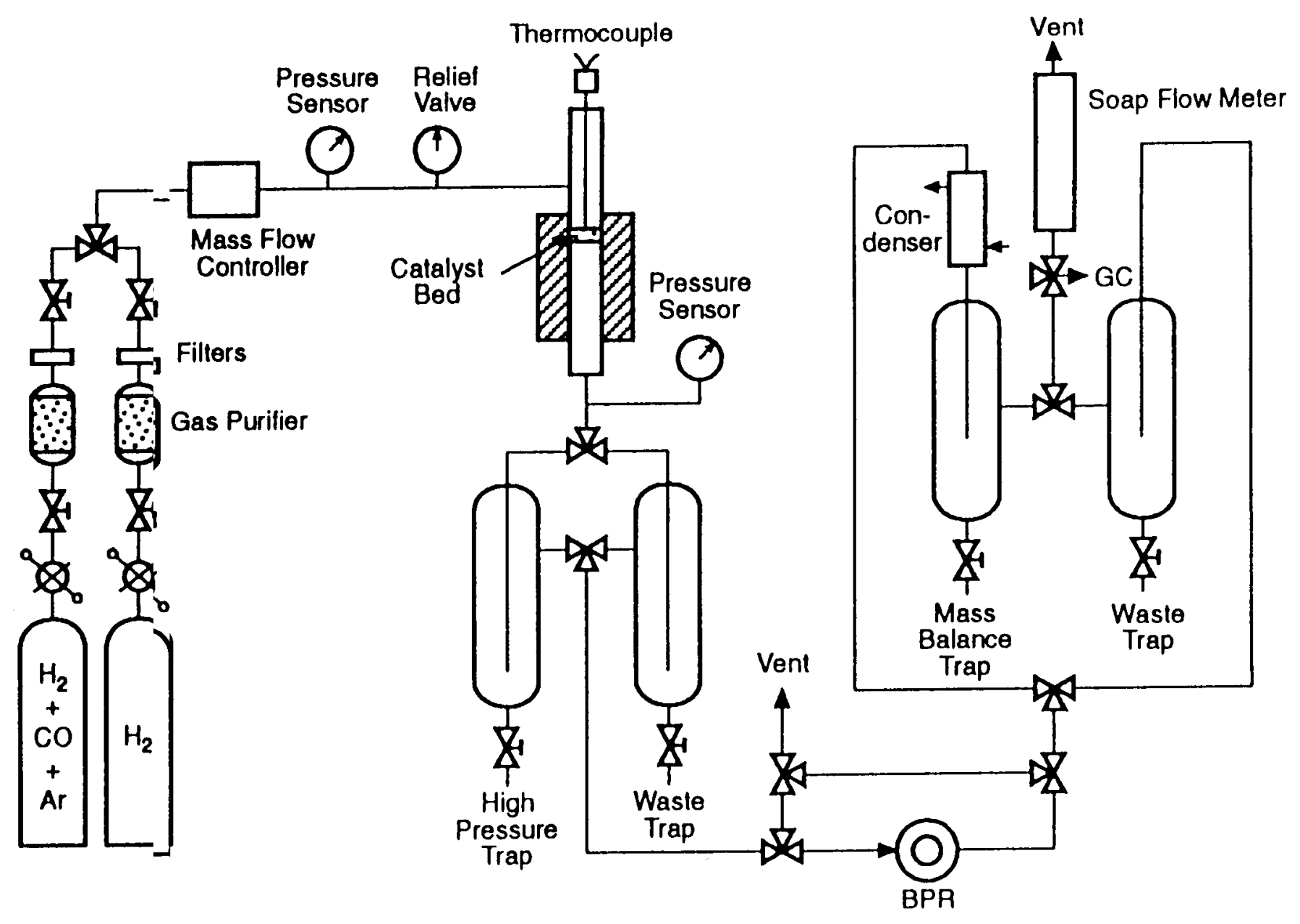

Figure 2. Schematic Diagram of the Laboratory-Scale Fixed-Bed Reactor 
hydrocarbons. The hydrocarbons $\mathrm{C}_{1}-\mathrm{C}_{15}$ and the oxygenates were analyzed using an HP-1 100 $\mathrm{m} \times 0.25 \mathrm{~mm} \times 0.5 \mu \mathrm{m}$ capillary column and detected by a flame ionization detector (FID). The $\mathrm{CO}, \mathrm{CO}_{2}$, and Ar were separated by a $2.6 \mathrm{ft} \times 1 / 8 \mathrm{in}$. Haysep Q column and $3.15 \mathrm{ft} \times 1 / 8 \mathrm{in}$. molecular sieve $13 \mathrm{X}$ columns and detected by TCD. The wax samples were analyzed using a SPB-1 $15 \mathrm{~m}$ x $0.53 \mathrm{~m}$ x $0.1: \mathrm{m}$ capillary column with an FID. The calibration was carried out using various calibration mixtures and pure compounds from Supelco and HP.

\subsection{RESULTS AND DISCUSSIONS}

Scanning electron microscopy (SEM) of binder silica and kaolin binder catalysts are shown in Figure 3. The catalyst is roughly spherical in shape, typical of a spray drying process, with diameters ranging from 30 to $90: \mathrm{m}$.

The attrition resistance of the silica binder based increased (attrition reduced) as binder level was increased up to $12 \%$ as shown in Table 2 . It then decreased when the binder level was increased to $20 \%$, indicating an optimum binder level of about 10 to $12 \%$. For this reason, this material was used as the basis for preparing the Fe- $\mathrm{KL}(\mathrm{y})$ series of catalysts. The Fe-KL(y) series of catalysts containing kaolin binder was prepared with $10 \mathrm{wt} \%$ binder silica. As seen in Table 2, the addition of kaolin from 8 to $24 \mathrm{wt} \%$ increased the attrition. The result here with kaolin is in agreement with literature (Datye et al., 1996).

Table 3 shows the BET surface areas of the fresh and reduced catalysts, and hydrogen uptake of all the catalysts synthesized. The BET surface area of the catalysts increased with silica concentration. However, there appears to be no effect on surface area as kaolin binder increased from 8 to $24 \mathrm{wt} \%$. In general, the addition of silica to iron FT catalysts is known to improve stability of the porous iron oxide/hydroxide network (Bukur et al., 1995a). Silica enters 


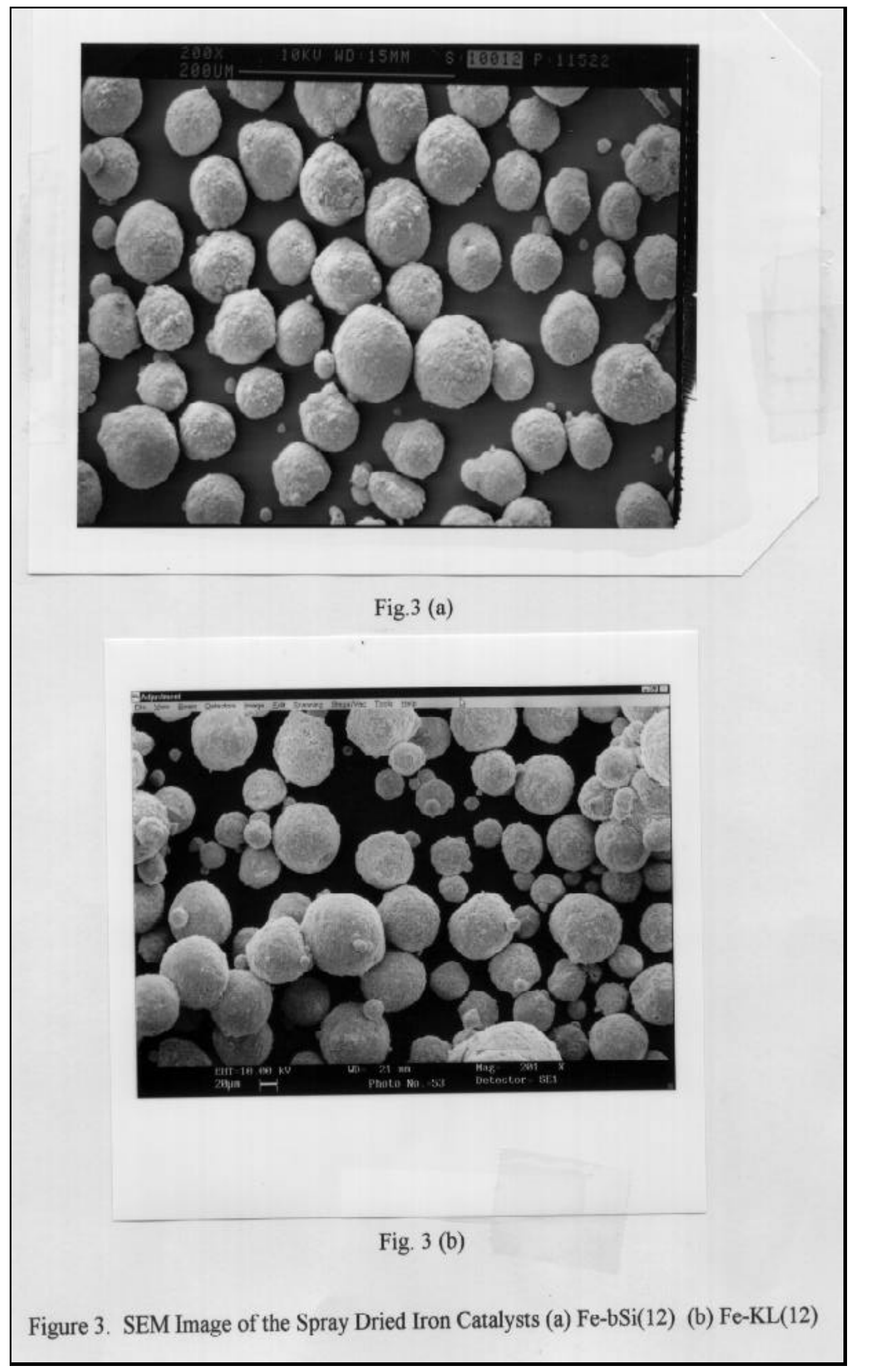


Table 2. ASTM Fluid Bed Test Results

\begin{tabular}{|l|c|c|}
\hline \multirow{2}{*}{ Catalyst Designation } & \multicolumn{2}{|c|}{ Attrition loss (wt \%) } \\
\cline { 2 - 3 } & $1 \mathrm{~h}$ & $5 \mathrm{~h}$ \\
\hline Fe-bSi(4) & 24.4 & 32.6 \\
\hline Fe-bSi(8) & 25.7 & 35.4 \\
\hline Fe-bSi(12) & 12.8 & 22.7 \\
\hline Fe-bSi(16) & 22.0 & 30.1 \\
\hline Fe-bSi(20) & 34.9 & 35.0 \\
\hline Fe-KL(8) & 8.8 & 27.9 \\
\hline Fe-KL(12) & 17.3 & 56.8 \\
\hline Fe-KL(16) & 8.4 & 27.6 \\
\hline Fe-KL(20) & 19.9 & 44.0 \\
\hline Fe-KL(24) & 17.9 & 54.1 \\
\hline Co035 & 31.07 & - \\
\hline
\end{tabular}


the pores of the original network of the catalysts, thus providing a rigid matrix which helps prevent a complete collapse of the pore structure of the catalyst. However, after reduction with $\mathrm{CO}$ at $280^{\circ} \mathrm{C}$ for $16 \mathrm{~h}$, the surface area of the reduced catalyst was lower than that of the fresh catalyst. This may be due to the formation of carbonaceous deposits, which causes blocking of the pores of the catalyst.

The reduction behavior of the FT catalysts was studied by TPR and the profiles for binder silica and kaolin binder catalysts are shown in Figure 4. There were slight variations among the catalysts, with all showing peaks at 320 and $750^{\circ} \mathrm{C}$. The peak at $320^{\circ} \mathrm{C}$ corresponds to the reduction of $\mathrm{Fe}_{2} \mathrm{O}_{3} \rightarrow \mathrm{Fe}_{3} \mathrm{O}_{4}$, and the peak at $750^{\circ} \mathrm{C}$ corresponds to the reduction of $\mathrm{Fe}_{3} \mathrm{O}_{4}$ to metallic iron. Thus, it can be seen that the reduction of $\mathrm{Fe}_{3} \mathrm{O}_{4}$ to $\mathrm{Fe}$ is more difficult step requiring temperatures greater than $600^{\circ} \mathrm{C}$ for its occurrence in temperature-programmed mode. The small shoulder peak at roughly $250^{\circ} \mathrm{C}$ is due to the reduction of $\mathrm{CuO} \rightarrow \mathrm{Cu}$. A summary of the TPR characterization results for all the catalysts studied is given Table 3. The hydrogen uptake generally decreased with silica content.

$\mathrm{X}$-ray powder diffraction patterns of the fresh, CO-activated sample after activation, and after $100 \mathrm{~h}$ of FT synthesis for the binder silica catalysts is shown Figure 5. The pattern has been plotted over 22 value ranging from $5^{\circ}$ to $75^{\circ}$. The pattern in Figure 5 shows that the "fresh" samples are identical and are comprised of $"-\mathrm{Fe}_{2} \mathrm{O}_{3}$. The catalyst activated at $280^{\circ} \mathrm{C}$, with $\mathrm{CO}$ for $16 \mathrm{~h}$ exhibits the peaks for $\mathrm{Fe}_{3} \mathrm{O}_{4}$ and $\mathrm{PFe}_{2.5} \mathrm{C}$. The "used" sample contain mainly $\mathrm{Fe}_{2.5} \mathrm{C}$. The results of XRD analysis of kaolin binder containing iron catalyst samples are shown in Figure 6. All five samples have two things in common (i) a fairly large amorphic component as indicated by the high background maxima at about $35^{\circ} 2 \theta$ and $62.5^{\circ} 2 \theta$ and (ii) the presence of what is best identified as $(\mathrm{Fe}, \mathrm{Al})_{3}(\mathrm{Si}, \mathrm{Al})_{2} \mathrm{O}_{5}(\mathrm{OH})_{4}$. The presence of silicate that the binder 


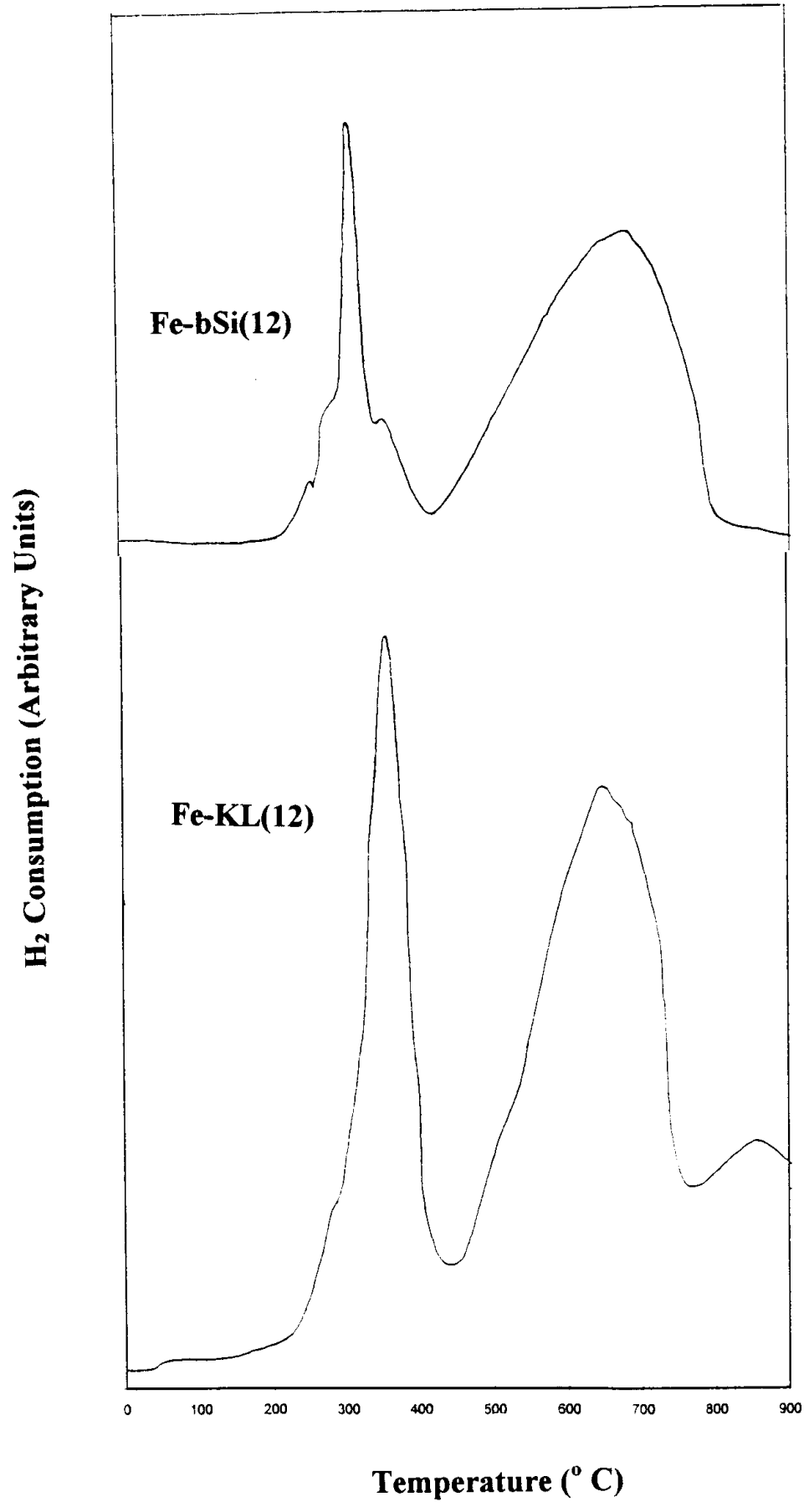

Figure 4. TPR Profile of (a) Fe-bSi(12) (b) Fe-KL(12)Catalysts 
Table 3. Physical and Chemical Properties of Fe Catalysts

\begin{tabular}{|l|c|c|c|}
\hline \multirow{2}{*}{ Catalyst Designation } & \multicolumn{2}{|c|}{$\begin{array}{c}\text { BET Surface Area, } \\
\mathrm{m}^{2} / \mathrm{g}\end{array}$} & \multirow{2}{*}{$\begin{array}{c}\text { TPR Measurements } \\
\mathrm{H}_{2} \text { Desorbed, } \\
\text { mmol/g.cat }\end{array}$} \\
\cline { 2 - 3 } & Fresh & Reduced & 24.3 \\
\hline Fe-bSi(4) & 80.3 & 35.6 & 23 \\
\hline Fe-bSi(8) & 95.7 & 50.8 & 20.6 \\
\hline Fe-bSi(12) & 121 & 68.7 & 19 \\
\hline Fe-bSi(16) & 151 & 103 & 18.4 \\
\hline Fe-bSi(20) & 172 & 98.9 & 22.8 \\
\hline Fe-KL(8) & 195 & NM & 21.5 \\
\hline Fe-KL(12) & 190 & NM & 21.6 \\
\hline Fe-KL(16) & 191 & NM & 21.1 \\
\hline Fe-KL(20) & 192 & NM & 22.5 \\
\hline Fe-KL(24) & 193 & NM & NM \\
\hline Ruhrchemie & 300 & NM & \\
\hline
\end{tabular}

NM=Not measured 


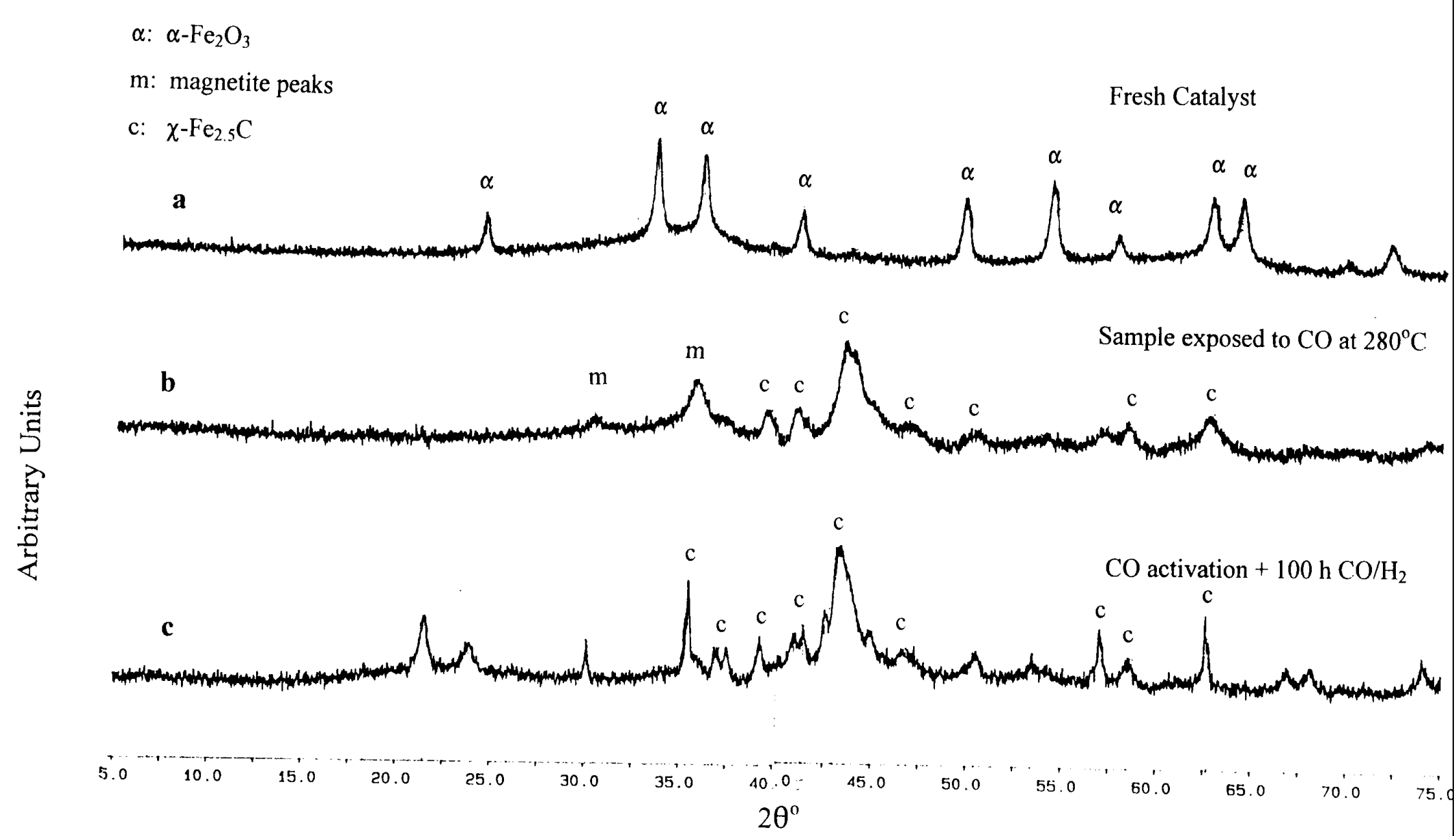

Figure 5. XRD Spectra of Fe-bSi(12) catalysts (a) As-Prepared Fresh Catalysts (b) Activtaion in CO for $16 \mathrm{~h}$ at $280^{\circ} \mathrm{C}$ (c) Activation in CO Followed by Fischer-Tropsch Synthesis for $100 \mathrm{~h}$ at $250^{\circ} \mathrm{C}$. 


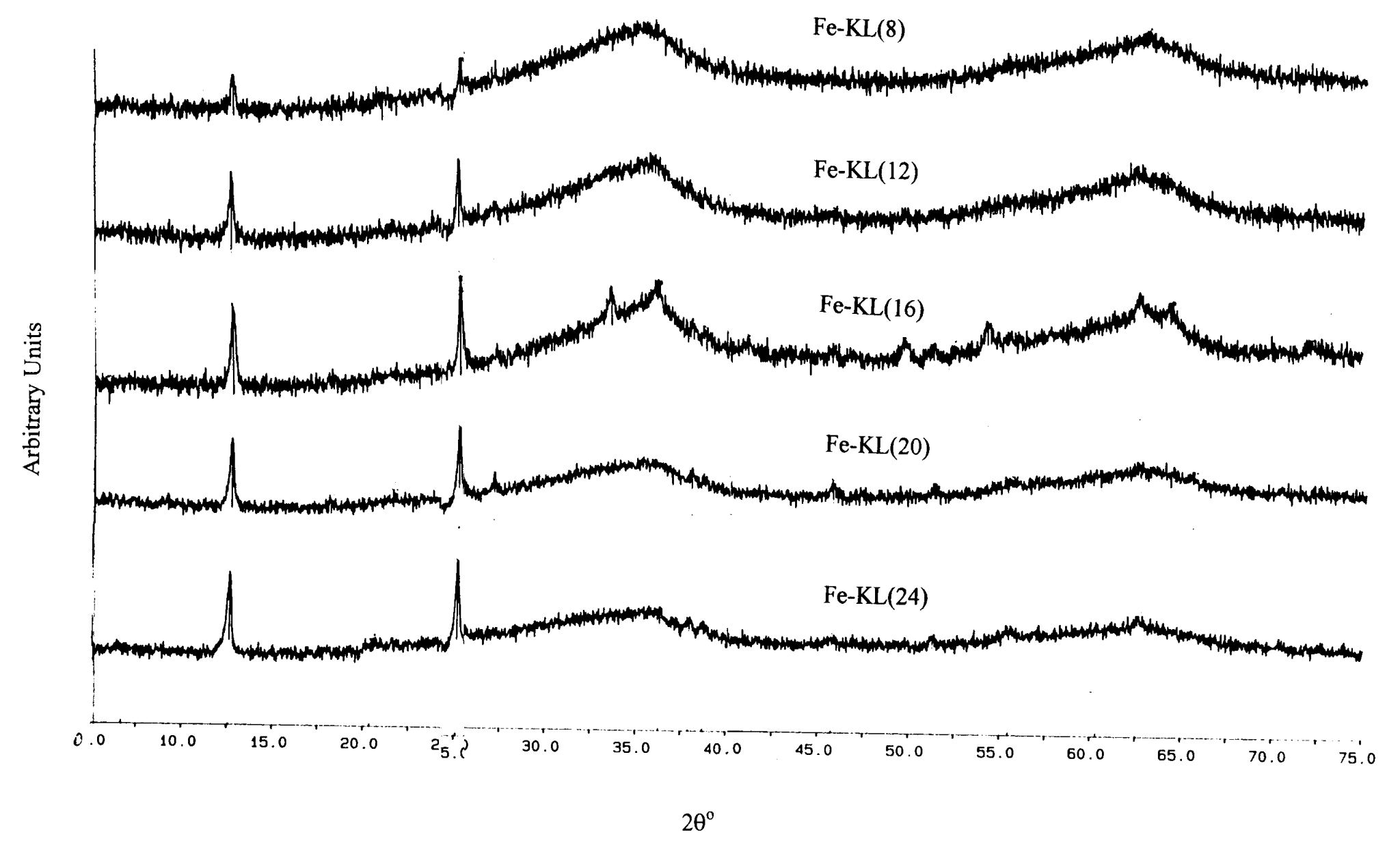

Figure 6. XRD Spectra of $\mathrm{Fe}-\mathrm{KL}(\mathrm{y})$ Iron Catalysts 
kaolinite that was added is not an inert component rather reacted within the system to provide the $\mathrm{Si}, \mathrm{Al}$, and $(\mathrm{OH})$. In fact, note the similarity in the stoichiometry for kaolinite $\left(\mathrm{Al}_{2} \mathrm{Si}_{2} \mathrm{O}_{5}(\mathrm{OH})_{4}\right)$ and the above compound. The kaolinite seems to have become the host for some of the Fe. With so much Fe added to the original system, it seems that the most of the iron added is contained in the amorphic phase.

The CO conversion plot for binder silica catalysts is shown Figure 7. All catalysts tested were more active than the Ruhrchemie catalyst. Table 4 shows the $\mathrm{CO}$ conversion and hydrocarbon selectivity for the various catalysts, along with the data on Ruhrchemie catalyst for comparison. Following a short induction period, during which steady state was achieved, there was no significant change with time in $\mathrm{CO}$ conversions or hydrocarbon selectivities reported in Table 4 over the test duration, typically 75 to $100 \mathrm{~h}$, for any of the catalysts. There was a beneficial effect of binder silica up to 8 to $12 \%$ on selectivity (reduced methane, nearly constant $\mathrm{C}_{5}{ }^{+}$). However, as binder silica content increased above $12 \%$, the $\mathrm{C}_{1}$ and $\mathrm{C}_{2}$ to $\mathrm{C}_{4}$ selectivities increased at the expense of $\mathrm{C}_{5}{ }^{+}$selectivity. The alpha value for all catalysts tested range from 0.87 to 0.91 . F-T reaction studies over 100 hours in a fixed-bed reactor showed that this catalyst maintained around $95 \% \mathrm{CO}$ conversion with a methane selectivity of less than $7 \mathrm{wt} \%$ and a $\mathrm{C}_{5}{ }^{+}$selectivity of greater than $73 \mathrm{wt} \%$.

The CO conversion plot for kaolin binder catalysts is shown in Figure 8. Catalyst containing up to $16 \mathrm{wt} \%$ binder clay were more active than the Ruhrchemie catalyst. Addition of clay binder beyond 16 wt \% however, resulted in decreased $\mathrm{CO}$ conversion. $\mathrm{CO}$ conversion dropped from 94 to $42.8 \%$ as kaolin content increased from 0 to 24 wt \%. The methane selectivity also increased with kaolin content up to $12 \mathrm{wt} \%$. 
Table 4. Catalyst Activity and Selectivity

\begin{tabular}{|c|c|c|c|c|c|c|}
\hline \multirow{2}{*}{$\begin{array}{l}\text { Catalyst } \\
\text { Designation }\end{array}$} & \multirow[t]{2}{*}{ CO Conversion $(\%)^{\mathrm{a}}$} & \multicolumn{4}{|c|}{ Selectivity } & \multirow[t]{2}{*}{ II } \\
\hline & & $\mathrm{C}_{1}$ & $\mathrm{C}_{2}-\mathrm{C}_{4}$ & $\mathrm{C}_{5}-\mathrm{C}_{11}$ & $\mathrm{C}_{12}{ }^{+}$ & \\
\hline $\mathrm{Fe}-\mathrm{bSi}(4)$ & 94.3 & 7.4 & 18.1 & 12.7 & 61.8 & 0.92 \\
\hline $\mathrm{Fe}-\mathrm{bSi}(8)$ & 94.1 & 6.8 & 17.6 & 13.0 & 62.5 & 0.91 \\
\hline Fe-bSi(12) & 94.3 & 6.8 & 19.6 & 12.8 & 60.8 & 0.89 \\
\hline Fe-bSi(16) & 95.5 & 9.9 & 25.0 & 17.3 & 47.8 & 0.87 \\
\hline Fe-bSi(20) & 94.5 & 9.6 & 23.5 & 17.6 & 49.3 & 0.87 \\
\hline $\mathrm{Fe}-\mathrm{KL}(8)$ & 88.5 & 9.1 & 24.8 & 25.4 & 40.7 & 0.88 \\
\hline Fe-KL(12) & 88.4 & 10.2 & 22.6 & 26.3 & 40.9 & 0.89 \\
\hline Fe-KL(16) & 92.9 & 9.8 & 26.1 & 24.5 & 39.6 & 0.87 \\
\hline $\mathrm{Fe}-\mathrm{KL}(20)$ & 79.1 & 9.3 & 19.7 & 29.7 & 41.3 & 0.88 \\
\hline Fe-KL(24) & 42.8 & 4.8 & 12.7 & 30.4 & 52.1 & 0.89 \\
\hline Ruhrchemie & 86 & 8.3 & 21.3 & 14.3 & 56.1 & 0.90 \\
\hline
\end{tabular}

${ }^{\mathrm{a}}$ Measured at $250^{\circ} \mathrm{C}, 1.48 \mathrm{MPa}, 2 \mathrm{NL} /$ g.cat $/ \mathrm{h}, \mathrm{H}_{2} / \mathrm{CO}=0.67$ 


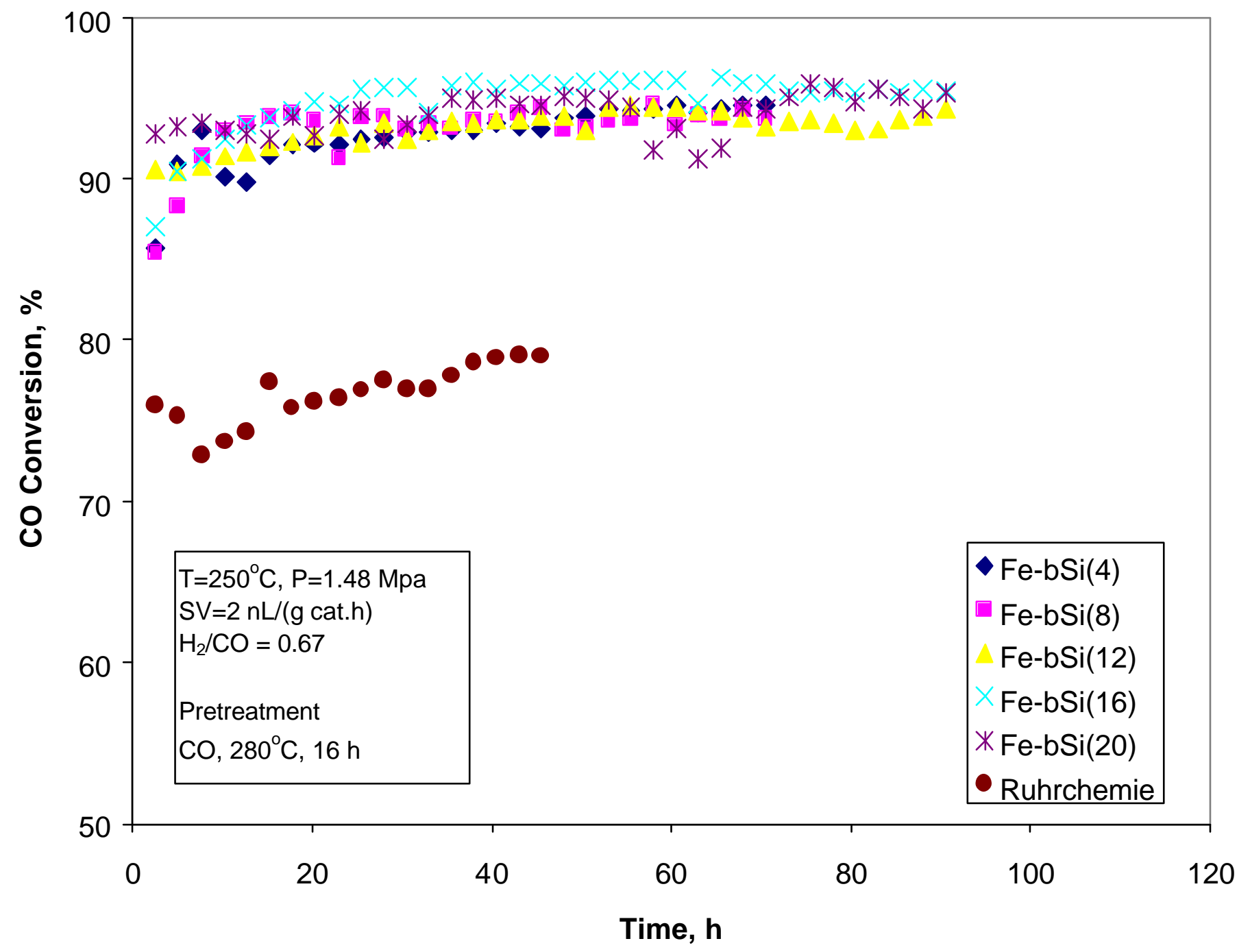

Figure 7. Effect of Binder Silica on Synthesis Gas Conversion and Catalyst Stability 


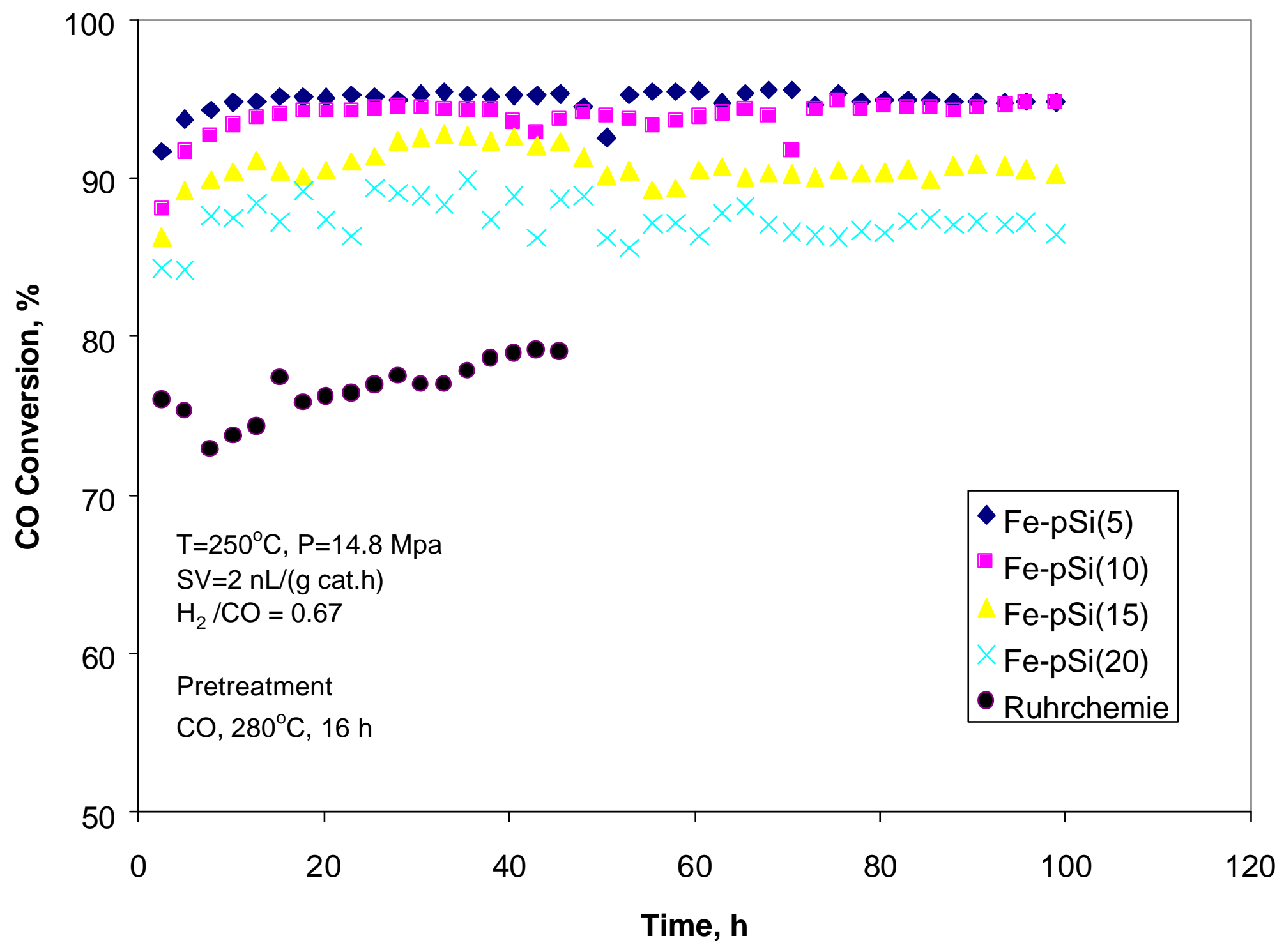

Figure 8. Effect of Precipitated Silica on Synthesis Gas Conversion and Catalyst Stability 


\subsection{CONCLUSIONS}

The addition of binder silica to precipitated $100 \mathrm{Fe} / 5 \mathrm{Cu} / 4.2 \mathrm{~K}$ FT catalyst followed by spray drying increases the attrition resistance significantly. Within the range of catalysts tested here, the optimum binder silica content is 10 to $12 \%$. The FT activity and selectivity of this catalyst are better than a Ruhrchemie catalyst at $250^{\circ} \mathrm{C}$ and $1.48 \mathrm{MPa}$. The comparison of the attrition results shows that some of the spray dried iron catalysts in their calcined state are physically as strong as, or stronger than, the cobalt catalysts. These iron catalysts are therefore considered to have a strong potential for SBCR use. A catalyst with $12 \%$ binder silica was found to have the highest attrition resistance. The addition of kaolin causes more attrition.

The FT activity and selectivity of the catalyst containing binder silica are better than a Ruhrchemie catalyst at 250 EC and 1.48 MPa. F-T reaction studies over 100 hours in a fixed-bed reactor showed that this catalyst maintained around $95 \% \mathrm{CO}$ conversion with a methane selectivity of less than $7 \mathrm{wt} \%$ and $\mathrm{a} \mathrm{C}_{5}{ }^{+}$selectivity of greater than $73 \mathrm{wt} \%$. Addition of kaolin binder to catalyst containing $10 \%$ binder silica was detrimental to FT activity. CO conversion dropped from 94 to $42.8 \%$ as kaolin content increased from 0 to 24 wt \%. The methane selectivity also increased with kaolin content up to $12 \mathrm{wt} \%$. The alpha value for all catalysts tested ranged from 0.88 to 0.91 .

Research needs to be focused on effective catalyst pretreatment procedure for iron FT catalysts that will produce catalyst with high activity, selectivity and longevity. Finally catalyst activity and selectivity should be evaluated in a slurry bubble column reactor. 


\subsection{REFERENCES}

Anderson, R.B., The Fischer-Tropsch Synthesis; Academic Press: Orlando, FL, 1984.

Bukur, D.B., Okabe, K., Rosynek, M.P., Li, C., Wang, D., Rao, K.R.P.M., and Huffman, G.P., J. Catal., 155, 353(1995a).

Bukur, D.B., Nowicki, L., Manne, R.K., and Lang, X., J. Catal., 155, 366(1995b)

Bukur, B.D., Mukesh, D., and Patel, S.A., Ind. Eng.Chem.Res., 29, 194(1990a).

Bukur, D.B., Lang, X., Mukesh, D., Zimmerman, W.H., Rosynek, M.P., and Li, C., J. Catal.,29, 1588(1990 b).

Butt, J.B., Catal .Lett., 7, 61(1990).

Dayte, A.K., Study. Surf.Sci.Catal., 101, 1421(1996).

Demmel, E.J., U.S. Patent, 5, 288,739(1994).

Donnelly, T.J., and Satterfield, C.N., Appl.Catal., 56, 231(1989).

Dry, M., in Catalysis:Science and Technology, Vol.1, ed.by Anderson, J.R., and Boudart,M., Springer-Verlag, NY, 1981

Kolbel, H., and Ralek, M., Catal.Rev.-Sci.Eng., 21, 225(1980).

O’Brien, R.J., Raje, A., Keogh, R.A., Spicer, R.L., Xu, L., Bao, S., Srinivasan, R., Houpt, D.J., Chokkram, S., and Davis, B.H., Coal Liquefaction and gas Conversion Contractors' Review Conference, 1995.

Pennline, H.W., Zarochak, M.F., Stencel, J.M., and Diehl, J.R., Ind.Eng. Chem.Res., 26, 595(1987)

Sault, A.G., and Datye, A.K., J. Catal., 140, 136(1993).

Zarochak, M.F., and McDonald, M.A., in Seventh DOE Indirect Liquefaction Contractors Meet.Proc., Pittsburgh, Dec 7-9, p.96(1987). 